\title{
Rola microRNA w różnicowaniu mięśni szkieletowych
}

\section{The role of microRNAs in the differentiation of the skeletal muscles}

\author{
Joanna Bujak ${ }^{1 * \varpi}$, Patrycja Kopytko ${ }^{1 * \varpi}$, Kamila Rydzewska $^{2}$, Marta Tkacz ${ }^{2}$, Maciej Tarnowski ${ }^{2}$ \\ ${ }^{1}$ Pomorski Uniwersytet Medyczny w Szczecinie, Studium Doktoranckie Wydziału Lekarskiego z Oddziałem Nauczania w Języku Angielskim, \\ ul. Żołnierska 54, 71-210 Szczecin \\ ${ }^{2}$ Pomorski Uniwersytet Medyczny w Szczecinie, Katedra i Zakład Fizjologii, al. Powstańców Wlkp. 72, 70-111 Szczecin \\ $\bowtie$ joanna.bujak@pum.edu.pl; patrycja.kopytko@pum.edu.pl
}

\begin{abstract}
Myogenesis is a complicated multi-step process which begins in utero. The development of skeletal muscles is regulated by many factors and signalling pathways that can additionally be controlled by microRNAs. MicroRNAs are a class of small, noncoding, endogenous RNA with a length of 21-25 nucleotides. MicroRNAs play an important role in the mechanisms of posttranscriptional regulation of gene expression by binding to the complementary mRNA causing its degradation, or inhibition of the protein translation process. Some miRNAs are only expressed in the skeletal muscles, playing a particularly important role
\end{abstract}

in the differentiation of muscle cells. The group of the musclespecific miRNA (myomiRs) includes: miR-1, miR-27b, miR-133, miR-195, miR-199, miR-206, miR-499. Elevated concentrations of muscular specific microRNA are typical for the late stage of muscle development, and their level is directly proportional to the ability of myoblasts to differentiate into myotubes. The dysregulation of myomiRs level can lead to the development of some pathologies, e.g. rhabdomyosarcoma, Duchenne muscular dystrophy, amyotrophic lateral sclerosis.

Keywords: myogenesis; development of muscle cells; myomiRs.

\begin{abstract}
ABSTRAKT
Miogeneza jest skomplikowanym i wieloetapowym procesem rozpoczynającym się w życiu płodowym. Rozwój mięśni szkieletowych regulowany jest przez liczne czynniki oraz ścieżki sygnalizacyjne, które mogą być kontrolowane przez microRNA. MicroRNA to krótkie, niekodujące odcinki RNA pochodzenia endogennego, o długości 21-25 nukleotydów. MicroRNA odgrywają istotną rolę $w$ mechanizmach potranskrypcyjnej regulacji ekspresji genów poprzez wiązanie z komplementarnym mRNA, powodując jego degradację lub inhibicję translacji białka. Wykryto, iż niektóre miRNA występują jedynie w tkance mięśniowej, odgrywając szczególnie ważną rolę w procesie
\end{abstract}

\section{MIOGENEZA}

Rozwój mięśni szkieletowych jest procesem wieloetapowym, w którym ważną rolę odgrywają czynniki genetyczne i środowiskowe [1]. Miogeneza rozpoczyna się ok. 20. dnia rozwoju zarodka. Dochodzi do rozdzielenia mezodermy i podzielenia jej na somity. Prekursorem komórki mięśniowej jest sarkoblast, komórka jednojądrzasta zawierająca w cytoplazmie dużo rybosomów o kształcie wrzecionowatym [2]. Nieocenioną rolę w specyfikacji mięśniowej somitu odgrywają białka PAX3 i PAX7, które uczestniczą w migracji, podziale, specyfikacji oraz różnicowaniu komórek mięśniowych. Białka: BMP, WNT, SHH i MSX inicjują podział somitu na dermomiotom i sklerotom [3]. W dermomiotomie następuje synteza mięśniowych czynników regulatorowych (mogenic regulatory factors - MRF) Myf4, Myf5 oraz MyoD, które odpowiadają za kontrolę ekspresji genów niezbędnych w dalszych procesach miogenezy. Pod wpływem różnicowania komórek mięśniowych. Do grupy mięśniowo specyficznych miRNA (myomiRs) zalicza się: miR-1, miR-27b, miR-133, miR-195, miR-199, miR-206, miR-499. Stan podniesionego stężenia mięśniowo charakterystycznych microRNA jest typowy dla późnego stadium różnicowania komórek mięśniowych, a ich ilość jest wprost proporcjonalna do zdolności różnicowania się mioblastów w miotubule. Dysregulacja stężenia myomiRs może prowadzić do rozwoju chorób mięśni szkieletowych, w tym: mięsaka prążkowanokomórkowego, dystrofii mięśniowej Duchenne'a, stwardnienia zanikowego bocznego. Słowa kluczowe: miogeneza; rozwój komórek mięśniowych; myomiRs. stymulacji białkami PAX3 i PAX7 dermomiotom ulega podziałowi na dermatom i miotom $[4,5,6]$. W wyniku aktywności mitotycznej i różnicowania niektórych komórek potomnych powstają mioblasty, podobne pod względem budowy do sarkoblastów, jednak nieposiadające właściwości komórek macierzystych. Postmitotyczna generacja mioblastów ulega fuzji w wielojądrzaste komórki o wydłużonym kształcie - tubule, inaczej miotuby [2]. Kolejnym etapem jest synteza białek charakterystycznych dla dojrzałej tkanki mięśniowej: aktyny, miozyny, kinazy kreatynowej oraz desminy [5, 6]. Kluczową rolę w procesie regeneracji komórek mięśniowych odgrywają komórki satelitarne (muscle satellite cells - MSC) znajdujące się między błoną włókna mięśniowego a błoną podstawną. Te niewielkie, bogate w heterochromatynę komórki w prawidłowych warunkach pozostają w fazie Go cyklu komórkowego, jednak w momencie urazu tkanki mięśniowej stają się źródłem mioblastów odbudowujących uszkodzone komórki mięśniowe. 
W miejscu uszkodzenia uwalniane są cytokiny oraz czynniki wzrostu regulujące proces fagocytozy uszkodzonych komórek mięśniowych oraz aktywację MSC. W pobudzeniu aktywności komórek satelitarnych uczestniczą również czynniki transkrypcyjne z rodziny MRF (Myf5, Myf6, MyoD) oraz miogenina. Szczególnie ważny jest wzrost ekspresji miogenicznego czynnika 5 i miogenicznego czynnika determinującego, niezbędny do wzbudzenia cyklu komórkowego MSC [7]. Aktywowane komórki satelitarne ulegają podziałom mitotycznym, różnicując się w mioblasty. Następuje fuzja mioblastów i powstanie miotub. Całość reakcji pozostaje pod ścisłą kontrolą białka $\mathrm{PAX}_{3}$ i PAX7. Obniżenie poziomu białka PAX7 związane jest z syntezą Myf5, Mrf4 oraz miogeniny, determinując dalsze etapy różnicowania. Część komórek satelitarnych zachowuje stały poziom białka PAX7, dzięki czemu możliwe jest odtworzenie niezróżnicowanej puli komórek satelitarnych. Całkowity czas regeneracji tkanki mięśniowej wynosi ok. 14 dni [8, 9].

\section{MicroRNA}

MicroRNA (miRNA) to krótkie, konserwatywne odcinki RNA pochodzenia endogennego o długości ok. 21-25 nukleotydów. MicroRNA uczestniczy w potranskrypcyjnej kontroli ekspresji genów i zaangażowany jest w procesy: proliferacji komórek, apoptozy, metabolizmu tłuszczów, tworzenia sieci neuronowych, różnicowania komórek hematopoetycznych [10]. Szacuje się, że miRNA reguluje ekspresję ok. 30\% wszystkich genów obecnych w organizmie człowieka [10, 11]. Pierwsze microRNA zostały odkryte w 1993 r. u larwy C. elegans. MicroRNA tworzone jest z pri-miRNA, z którego uwalniany jest prekursor miRNA lub pre-miRNA. Ten proces jest możliwy dzięki aktywności RNazy III Drosha. Gotowe pre-miRNA transportowane jest z jądra komórkowego do cytoplazmy za pomocą Ran-GTP i Exportyny-5. Jeden koniec dojrzałego miRNA definiowany jest przez RNaze III Drosha, a drugi poprzez działanie enzymu Dicer. Aktywność enzymu prowadzi do powstania duplexu miRNA:miRNA*, który następnie rozplatany jest przez helikazę. Dojrzałe miRNA łączy się z białkiem AGO (argonaute protein), tworząc kompleks miRISC zdolny do połączenia się z mRNA (ryc. 1). Wykazano, że do efektywnego zahamowania mRNA wystarczy komplementarny odcinek miRNA o długości

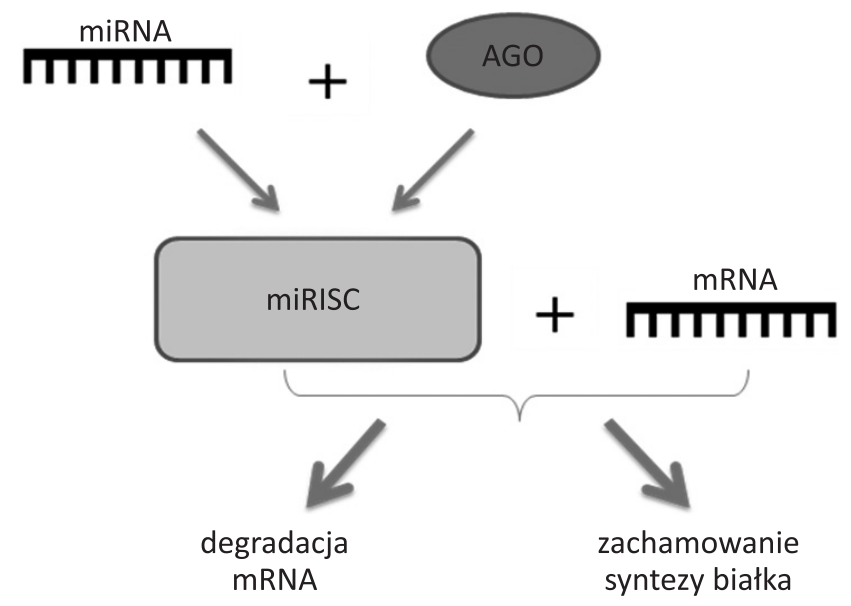

RYCINA 1. Powstawanie kompleksu miRISC
8 nukleotydów. Zespolenie kompleksu wyciszającego miRISC z mRNA skutkuje degradacją mRNA lub zahamowaniem syntezy białka $[12,13,14]$.

MicroRNA mogą wykazywać ekspresję we wszystkich tkankach lub posiadać specyficzność tkankową. Do miRNA charakterystycznych dla tkanki mięśniowej należą m.in.: miR1-1, miR1-2, miR-133a-1, miR-133a-2, miR-183, miR-206, miR-499 [15]. Grupa miRNA, charakterystyczna dla komórek mięśniowych, nazywana jest myomiR. MyomiR wykazują wysoką ekspresję podczas różnicowania komórek mięśni szkieletowych i serca, a ich funkcje można zaobserwować u wielu gatunków takich jak Drosophila czy C. elegans [16].

\section{WYBRANE MIRNA I ICH UDZIAŁ W MIOGENEZIE}

Stan podniesionego stężenia mięśniowo charakterystycznych microRNA jest typowy dla późnego stadium różnicowania komórek mięśniowych, a ich ilość jest wprost proporcjonalna do zdolności różnicowania mioblastów w miotubule [17].

\section{miR-1/206}

Wśród mięśniowo specyficznych miRNA kluczową rolę odgrywa rodzina miR-1/206, której składowe są niezbędne do prawidłowego rozwoju mięśni szkieletowych oraz mięśnia sercowego. U kręgowców miR-1 oraz miR-206 są wysoce konserwatywne, a sekwencje obu myomiRów różnią się między sobą jedynie 4 nukleotydami $[18,19]$. Podobna sekwencja miR-1 i miR-206 umożliwia regulację ekspresji tych samych genów, choć uważa się, że miR-206 odgrywa ważniejszą rolę w procesie różnicowania komórek mięśniowych, ponieważ wykazuje wyższe stężenie w różnicującej się tkance mięśniowej w porównaniu z miR-1 [20]. Głównym zadaniem obu miRNA jest regulacja poziomu MRFs; miR-1 i miR-206 wzmagają ekspresję miogeniny [21]. Ponadto ich celem jest gen miostatyny (MSTN), z którym wiążą się w sekwencji 3'UTR. Obecność mutacji w regionie 3'UTR MSTN uniemożliwia przyłączenie się komplementarnych myomiRów i może prowadzić do zaburzenia ekspresji miostatyny [19]. Ilość miR-206 może być regulowana przez MyoD (ryc. 2). Miogeniczny czynnik różnicujący wiąże się bezpośrednio do promotora miR-206, kontrolując w ten sposób ekspresję miRNA w tkance mięśniowej. Nadekspresja MyoD powoduje wzrost stężenia miR-206, zwiększając tym samym zdolność różnicowania mioblastów [17]. Rodzina miR-1/206 decyduje o mięśniowych komórkach satelitarnych poprzez regulację genu $P A X 7$. Komórki Pax7 $7^{+} / \mathrm{MyoD}^{-}$znajdują się w fazie spoczynkowej, ponieważ ich fuzja jest niekompletna i nieefektywna. Podwyższona ilość obu miRNA obniża poziom białka PAX7 i powoduje wzrost MyoD, prowadząc do dalszej specyfikacji komórek MSC, zaś zablokowanie ich ekspresji powoduje odnawianie puli mięśniowych komórek satelitarnych [22, 23]. Stężenie miR-206 jest ściśle skorelowane z HDAC4 i obniża poziom deacetylaz histonowych, które są odpowiedzialne za supresję miogenicznych czynników regulacyjnych: Myf5, Mrf4 i miogeniny. Dodatkowo miR-206 sprawuje kontrolę nad prawidłową aktywnością szlaku TGF- $\beta 1 /$ Smad3 


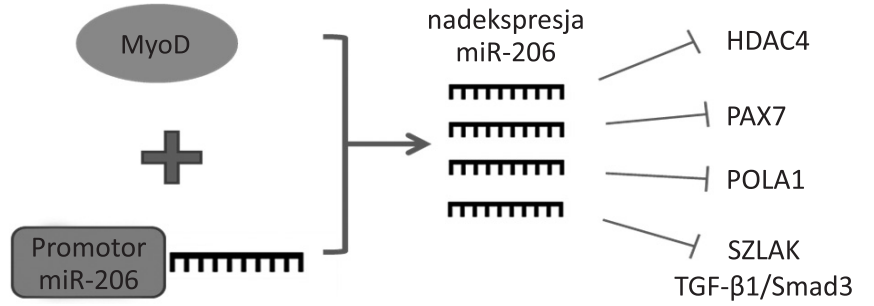

RYCINA 2. MyoD przyłącza się do promotora miR-206, powodując nadekspresję miR-206. Podwyższony poziom miR-206 hamuje HDAC4, PAX7, POLA1, szlak TGF- $\beta 1 /$ Smad3

zaangażowanego w rozwój i regenerację tkanek. Zahamowanie sygnalizacji TGF- $\beta 1 / S_{3}$ ad3 i obniżenie poziomu HDAC4 prowadzi do aktywacji MSCs [17, 22, 24]. Nadekspresja miR-206 prowadzi do wyciszenia genu POLA1 odpowiedzialnego za syntezę DNA. Zatrzymanie cyklu komórkowego i zahamowanie syntezy DNA jest kluczowym momentem podczas miogenezy prowadzącym do obniżenia tempa proliferacji mioblastów, stymulując ich formowanie w miotuby [20, 25]. Nadekspresja miR-206 indukuje wzrost białek p21 oraz p27 i prowadzi do zatrzymania cyklu komórkowego mioblastów w fazie G1 [20].

\section{miR-27b}

miR-27b odgrywa ważną rolę podczas rozwoju embrionalnego, uczestniczy w procesie adipogenezy, angiogenezy oraz reguluje proces różnicowania komórek mięśniowych, kontrolując ekspresję genów $P A X_{3}$ i $M E F 2 C$ [26, 27]. Podwyższone stężenie miR-27b występuje w zaktywowanych komórkach satelitarnych oraz w regenerującym się mięśniu. Nadekspresja miR-27b powoduje wyciszenie $P A X_{3}$ w miotomie, migrację komórek progenitorowych i ich dalszą specyfikację [26, 28]. Czynnikiem determinującym regulację $P A X_{3}$ za pomocą miR-27b jest sekwencja 3'UTR mRNA genu PAX3 zależna od długości odcinka polyA, który różni się w poszczególnych formach składania mRNA. Dłuższe odcinki polyA umożliwiają sukcesywne przyłączenie się miR-27b, powodując wyciszenie ekspresji genu $P A X_{3}[26,29]$. Ponadto miR-27b kontroluje poziom miostatyny poprzez regulację ekspresji genu MSTN. Wykazano silną korelację pomiędzy niskim poziomem miostatyny a wysoką ekspresją miR-27b. miR-27b jest komplementarny do sekwencji genu miostatyny. Komórki z funkcjonalnym genem MSTN transfekowane badanym miRNA nie wykazują ekspresji miostatyny, natomiast w komórkach posiadających mutację w sekwencji 3'UTR mRNA nie odnotowuje się różnic $\mathrm{w}$ poziomie miostatyny w porównaniu z komórkami grupy kontrolnej [30]. Nadekspresja miR-27b tłumi aktywność genów $M E F 2 C$, powodując podwyższoną ekspresję inhibitorów rodziny MyoD [27]. Dodatkowo miR-27b inicjuje proces regeneracji mięśni, wpływając na aktywność Gai2 oraz na proliferację i różnicowanie mięśniowych komórek satelitarnych. Obniżony poziom miR-27b koreluje z niskim poziomem Gai2, co w konsekwencji prowadzi do zmniejszonej ekspresji MyoD i Myf5 [31].

\section{miR-133}

Rodzina miR-133 składa się z dwóch cząsteczek - miR-133a i miR-133b, które zlokalizowane są na różnych chromosomach [32].
Ich ekspresja występuje zarówno w mięśniu sercowym, jak i mięśniach szkieletowych. miR-133a/b należą do myomiRs sprawujących kontrolę nad mięśniowymi prekursorami oraz zapewniają miogenną homeostazę tkankową. Lokalne zastosowanie połączenia miR-1, miR-133 oraz miR-206 indukuje wzrost poziomu myoD1, pax7 i miogeniny, powodując tym samym różnicowanie mioblastów w szczurzym modelu urazu mięśniowego [33]. Wykryto, że miR-133 reguluje ekspresję genu kodującego receptor insulinopodobnego czynnika wzrostu 1 (insulin-like growth factor 1 receptor - IGF1R). Miejscem wiązania miR-133 jest konserwatywny region 3'UTR IGF1R. Obniżenie ilości miR-133 znacznie hamuje ekspresję białka na etapie potranskrypcyjnym. Wzrost ekspresji miR-133 lub obniżenie IGF1R skutkuje zmniejszeniem fosforylacji Akt szlaku sygnałowego IGF/PI3K/Akt [34]. Rodrigues i wsp. wykryli ścisły związek pomiędzy miR-133 a regulacją IGF1R. Wykazano, iż miR-133a hamuje ekspresję IGF1R oraz ścieżkę sygnalizacyjną odpowiedzialną za powstawanie mięśni szkieletowych, co może oznaczać, że miR-133a może być potencjalnym celem terapeutycznym w chorobach mięśniowych. Obniżenie stężenia miR-1a i podwyższenie ilości miR-133a może być związane ze spowolnieniem miogenezy w mięśniach szkieletowych u myszy z insulinoopornością. Włączenie wysokotłuszczowej diety powoduje obniżenie ekspresji IGF1 oraz IGF1R, co w konsekwencji podwyższa stężenie miR-133a [35, 36]. Pośrednim celem dla miR-133 jest SRF (serum response factor), który jest kluczowym czynnikiem proliferacji i różnicowania mięśni in vitro i in vivo. miR-133, regulując ekspresję genu Malat1, kontroluje stężenie SRF. Wykazano, że zahamowanie ekspresji Malat1 powoduje obniżenie poziomu SRF, co wzmaga proliferację mioblastów [37, 38]. Wzrost ekspresji miR-133a i miR-133b zauważalny jest także podczas rozwoju Piaractus mesopotamicus. Przypuszcza się, iż ekspresja miR-133a i miR-133b jest istotnym czynnikiem regulującym rozwój mięśni szkieletowych u P. mesopotamicus poprzez kontrolowanie proliferacji i różnicowania, a także specyfikacji włókien mięśniowych [39].

\section{miR-195}

miR-195 jest jednym z sześciu wysoce konserwatywnych miRNA wchodzących w skład rodziny miR-15, które zlokalizowane są na trzech różnych chromosomach. Stężenie miRNA z rodziny miR-15 ulega podwyższeniu w okresie postnatalnym, jest ważnym czynnikiem regulującym zatrzymanie cyklu komórkowego kardiomiocytów oraz hamuje ich proliferację [40]. Istnieje negatywny związek pomiędzy miR-195 a regulacją rozwoju naczyń krwionośnych [41]. Wykazano, iż miR-195/497 zaangażowane są w wyciszenie komórek satelitarnych. Odpowiedzialne są za zatrzymanie cyklu komórkowego w fazie G1/S i G2/M poprzez regulację ekspresji genów CDC25 oraz CCND2 [42].

Zhao i wsp. wykryli, że stężenie miR-195 ulega podwyższeniu w rozwoju i różnicowaniu mięśni. Badany miR regulowany

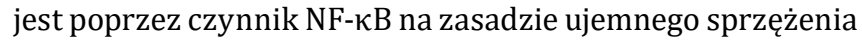
zwrotnego. miR-195 oddziałuje na geny związane z regulacją cyklu komórkowego oraz odpowiedzialne za wzrost komórek. Do głównych celów działania miR-195 należą geny: $C C N D 2$, CCNE1, IGF1R oraz INSR [43]. 


\section{miR-199}

miR-199a-5p pełni ważną rolę w regulacji połączeń międzykomórkowych i sprawuje kontrolę nad wieloma procesami biologicznymi, w tym rozwoju cytoszkieletu, cyklu komórkowego oraz szlaku sygnalizacyjnego WNT [44]. Wykazano, że nadekspresja miR-199a-5p jest jednym z czynników leżących u podłoża postępującego procesu hipertrofii kardiomiocytów [45]. Ponadto wykryto wysokie stężenie miR-199a-3p podczas różnicowania komórek $\mathrm{C} 2 \mathrm{C} 12$. Molekularnym celem badanego miRNA jest szlak sygnalizacyjny IGF1/AKT/mTOR. Wzrost ekspresji miR-199a-3p częściowo blokuje różnicowanie mięśni i aktywuje szlak sygnałowy AKT/mTOR. Zastosowanie inhibitora miR-199a-3p powoduje wzrost myoG oraz myhc, w konsekwencji wpływając na różnicowanie i hipertrofię miotubul [46]. Przypuszcza się, iż miR-199b jest zaangażowany w różnicowanie komórek iPS (induced pluripotent stem cells) do komórek ECs (endothelial cells). Celem miR-199b jest ligand JAG1 genu Notch, który ma kluczowe znaczenie w produkcji VEGF - niezbędnego czynnika kierującego różnicowanie komórek iPS do komórek śródbłonka [47].

\section{miR-499}

miR-499 uczestniczy w regulacji ścieżek sygnalizacyjnych związanych z rozwojem, różnicowaniem i homeostazą mięśni szkieletowych [48]. Jest niezbędny do określenia tożsamości włókien mięśniowych poprzez aktywację genów odpowiedzialnych za powstawanie włókien wolnokurczliwych i dezaktywację genów promujących różnicowanie włókien szybkokurczliwych [49]. Bezpośrednim celem miR-499 jest gen SOX6, który posiada 1-4 miejsc zdolnych do wiązania miR-499. Przyłączenie miR-499 do sekwencji 3'UTR SOX6 skutkuje represją aktywności blokowanego genu, wpływając na obniżenie poziomu genów MHC1 i TNNC1 [39, 48, 50]. Istnieje zależność pomiędzy wzrostem ilości miR-499 a obniżeniem ekspresji SOX6 podczas formowania włókien wolnokurczliwych u P. mesopotamicus. Po zróżnicowaniu włókien mięśniowych wykrywany jest spadek stężenia miR-499 i reekspresja genu SOX6 [39]. Wykazano, że nadekspresja miR-499 w mięśniach szkieletowych myszy powoduje przejście mięśni szybkokurczliwych w mięśnie wolnokurczliwe [39, 49]. Analiza ilości miRNA we włóknach mięśniowych białych i czerwonych wskazuje widoczną dysproporcję w stężeniu miR-499. Włókna mięśniowe wolnokurczliwe charakteryzują się wyższym stężeniem miR-499 i obniżoną ekspresją genu SOX6, natomiast we włóknach szybkokurczliwych tendencja jest odwrotna [51].

Ponadto miR-499 reguluje aktywność genu ROD1 odpowiedzialnego za różnicowanie komórek, prowadząc do jego deadenylacji lub degradacji powstającego białka. Ekspresja genu ROD1 sprawuje kontrolę nad miogenezą poprzez pośrednie działanie na deacetylazy histonów [51].

W tabeli 1 przedstawiono zaburzenia regulacji ekspresji miRNA i ich wpływ na miogenezę.

\section{ZABURZENIA EKSPRESJI MIRNA W CHOROBACH MIĘŚNI SZKIELETOWYCH}

MicroRNA, kontrolując ekspresję genów, może przyczyniać się do rozwoju chorób mięśni szkieletowych, w tym: mięsaka prążkowanokomórkowego (RMS), dystrofii mięśniowej Duchenne'a (DMD), stwardnienia zanikowego bocznego (ALS).

Mięsak prążkowanokomórkowy (Rhabdomyosarcoma) jest nowotworem złośliwym tkanek miękkich wywodzącym się z mezenchymy lub z neuroektodermy [52]. Przypuszcza się, iż rhabdomyoblasty powstają z mięśniowych komórek progenitorowych, które na drodze transformacji nowotworowej i w wyniku molekularnych defektów utraciły zdolność różnicowania w dojrzałe komórki mięśniowe [53]. Analiza stężeń miR-1 oraz miR-133-a wskazuje na znacznie niższe ilości mięśniowo specyficznego miRNA w guzach pacjentów chorych na RMS w porównaniu z grupą kontrolną składającą się ze zdrowych ochotników. Ponadto istnieją różnice w stężeniu miR-1 i miR-133-a pomiędzy typem pęcherzykowym (rhabdomyosarcoma alveolare - ARMS) a zarodkowym (rhabdomyosarcoma

TABELA 1. Zaburzenia regulacji ekspresji miRNA $\mathrm{i}$ ich wpływ na miogenezę

\begin{tabular}{|c|c|c|c|}
\hline $\operatorname{miR}$ & Poziom miR & Gen docelowy & Efekt \\
\hline \multirow{2}{*}{ miR-1 } & nadekspresja & MSTN & zaburzenia ekspresji miostatyny \\
\hline & nadekspresja & PAX7 & zahamowanie ekspresji, wzbudzenie komórek MSC do różnicowania \\
\hline \multirow{3}{*}{$\operatorname{miR}-27 b$} & nadekspresja & PAX3 & wyciszenie ekspresji, migracja komórek progenitorowych i ich dalsza specyfikacja \\
\hline & nadekspresja & MSTN & obniżenie poziomu miostatyny \\
\hline & nadekspresja & MEF2C & obniżenie ekspresji, podwyższona ekspresja inhibitorów rodziny MyoD \\
\hline $\operatorname{miR}-133$ & nadekspresja & IGF1R & zahamowanie ekspresji, obniżenie poziomu białka \\
\hline \multirow{2}{*}{ miR-195 } & nadekspresja & CDC25 i CCND2 & wyciszenie MSCs i zatrzymanie cyklu komórkowego \\
\hline & nadekspresja & IGF1R i INSR & hamowanie proliferacji mioblastów \\
\hline \multirow{2}{*}{ miR-199 } & nadekspresja & WNT & wpływ na proliferację i różnicowanie mioblastów \\
\hline & nadekspresja & IGF1/AKT/mTOR & zahamowanie aktywności szlaku, hamowanie aktywności myoG oraz myhc \\
\hline \multirow{3}{*}{ miR-206 } & nadekspresja & MSTN & zaburzenia ekspresji miostatyny \\
\hline & nadekspresja & PAX7 & zahamowanie ekspresji, wzbudzenie komórek MSC do różnicowania \\
\hline & nadekspresja & HDAC4/TGF- $\beta 1 / S m a d 3$ & zahamowanie ekspresji, reekspresja miogenicznych czynników regulacyjnych \\
\hline \multirow{2}{*}{$\operatorname{miR}-499$} & nadekspresja & SOX6 & obniżenie ekspresji, obniżenie poziomu genów MHC1 i TNNC1 \\
\hline & nadekspresja & ROD1 & pośrednie działanie na HDAC4 \\
\hline
\end{tabular}


embryonale - ERMS). Typ zarodkowy wykazuje niższą ekspresję myomiRów, co potwierdza tezę, iż defekt powodujący błędne różnicowanie rhabdomyoblastów do dojrzałych komórek mięśniowych w ERMS powstaje we wcześniejszym etapie miogenezy niż w podtypie ARMS [54]. Dodatkowo spadek ekspresji myomiR (miR-1, miR-133a, miR-206) prowadzi do nadmiernej proliferacji, migracji oraz niekontrolowanej miogenezy, przyczyniając się do rozwoju mięsaka prążkowanokomórkowego [15].

Dystrofia Mięśniowa Duchenne’a jest chorobą dziedziczną, która spowodowana jest delecją lub mutacją genu dystrofiny odpowiadającego za utrzymanie prawidłowej struktury komórek mięśniowych [55]. miR-206 hamuje powstawanie urotropiny będącej paralogiem dystrofiny. Urotropina może zastąpić dystrofinę w mięśniach szkieletowych i hamować rozwój choroby [31, 56, 57]. Natomiast miR-143 reguluje poziom $\beta$-dystrobrewiny, istotnej dla prawidłowego funkcjonowania kompleksów DPC (dystrophin-associated protein complex) w mózgu. Obniżenie poziomu $\beta$-dystrobrewiny prowadzi do postępujących zaburzeń funkcji poznawczych związanych z DMD [58].

Stwardnienie zanikowe boczne należy do grupy chorób neurodegeneracyjnych, której istotą jest porażenie neuronów prowadzące do stopniowego upośledzenia funkcji mięśni ciała [59]. W porównaniu z osobami zdrowymi u chorych na ALS wykrywane jest podwyższone stężenie: miR-206, miR-23a, miR-29b, miR-31, miR-214, miR-455 [60, 61].

Większość mechanizmów regulujących ekspresję genów odpowiadających za różnicowanie mioblastów za pomocą miRNA pozostaje nieznana, dlatego dysregulacja kanonicznych myomiRów może świadczyć o rozwijającym się procesie chorobowym. Dostępne narzędzia biologii molekularnej w przyszłości mogą umożliwić wykorzystanie miRNA jako markerów różnicowania komórek mięśniowych [62].

\section{PIŚMIENNICTWO}

1. Luo W, Wu H, Ye Y, Li Z, Hao S, Kong L, et al. The transient expression of miR-203 and its inhibiting effects on skeletal muscle cell proliferation and differentiation. Cell Death Dis 2014;5(7):e134

2. Grabiec K, Milewska M, Grzelkowska-Kowalczyk K. Matczyna otyłość a rozwój mięśni szkieletowych u potomstwa - płodowe pochodzenie zaburzeń metabolicznych. Postępy Hig Med Dośw 2012;66:1-10.

3. Bartel H. Embriologia. Warszawa: Wydawnictwo Lekarskie PZWL; 2001. p. 101-427.

4. Przewoźniak M, Brzóska E. Białka PAX w różnicowaniu komórek i organogenezie. Post Biol Komórki 2008;35(2):229-42.

5. Archacka K, Kowalski K, Brzóska E. Czy komórki satelitowe są macierzyste? Post Bioch 2013;59(2):205-18

6. Milewska M, Grabiec K, Grzelkowska-Kowalczyk K. Interakcje szlaków sygnałowych proliferacji i różnicowania w miogenezie. Postępy Hig Med Dośw 2014;68:516-26.

7. McCormick R, Pearson T, Vasilaki A. Manipulation of environmental oxy gen modifies reactive oxygen and nitrogen species generation during myogenesis. Redox Biol 2016;8:243-51.

8. Czerwińska AM, Ciemerych MA. Kule zarodkowe jako metoda różnicowania pluripotencjalnych komórek macierzystych w mioblasty. Post Biol Komórki 2012;39(4):669-84.
9. Ławniczak A, Kmieć Z. Zmiany mięśni szkieletowych w trakcie starzenia: fizjologia, patologia i regeneracja. Postępy Hig Med Dośw 2012;66:392-400.

10. Wahida F, Shehzada A, Khanb T, Kima YY. MicroRNAs: synthesis, mechanism, function, and recent clinical trials. Biochim Biophys Acta 2010;1803(11):1231-43. doi: 10.1016/j.bbamcr.2010.06.013.

11. Honardoost M, Soleimani M, Arefian E, Sarookhani MM. Expression change of miR-214 and miR-133 during muscle differentiation. Cell J 2015;17(3):461-70.

12. Lujambio A, Calin GA, Villanueva A, Ropero S, Sanchez-Cespedes M, Blanco D, et al. A microRNA DNA methylation signature for human cancer metastasis. Proc Natl Acad Sci U S A 2008;105(36):13556-61. doi: 10.1073/pnas.0803055105.

13. Leoni G, Tramontano A. A structural view of microRNA-target recognition. Nucleic Acids Rec 2016;44(9):e82.

14. Bartel DP. MicroRNAs: genomics, biogenesis, mechanism, and function. Cell 2004;116(2):281-97.

15. Sun X, Guo W, Shen JK, Mankin HJ, Hornicek F, Duan Z. Rhabdomyosarcoma: advances in molecular and cellular biology. Sarcoma 2015;2015:232010.

16. Goljanek-Whysall K, Sweetman D. MicroRNAs in skeletal muscle differentiation and disease. Clin Sci 2012;123:611-25.

17. Koutalianos D, Koutsoulidou A, Mastroyiannopoulos MP, Furling D, Phylactou LA. MyoD transcription factor induces myogenesis by inhibiting Twist-1 through miR-206. J Cell Sci 2015;128,3631-45.

18. Jia X, Lin H, Abdalla BA, Nie Q. Characterization of miR-206 promoter and its association with birthweight in chicken. Int J Mol Sci 2016;17(4):559.

19. Ma G, Wang Y, Li Y, Cui L, Zhao Y, Zhao B, et al. MiR-206, a key modulator of skeletal muscle development and disease. Int J Biol Sci 2015;11(3):345-52.

20. Kim HK, Lee YS, Sivaprasad U, Malhotra A, Dutta A. Muscle-specific microRNA miR-206 promotes muscle differentiation. J Cell Biol 2006;174(5):67787.

21. Luo Y, Wu X, Ling Z, Yuan L, Cheng Y, Chen J, et al. microRNA133a targets Foxl2 and promotes differentiation of $\mathrm{C} 2 \mathrm{C} 12$ into myogenic progenitor cells. DNA Cell Biol 2015;34(1):29-36.

22. Huang Q-K, Qiao H-Y, Fu M-H, Li G, Li W-B, Chen Z, et al. MiR-206 attenuates denervation-induced skeletal muscle atrophy in rats through regulation of satellite cell differentiation via TGF- $\beta 1$, Smad3, and HDAC4 signaling. Med Sci Monit 2016;22:1161-70. doi: 10.12659/MSM.897909.

23. Chen J-F, Tao Y, Li J, Deng Z, Yan Z, Xiao X, et al. microRNA-1 and microRNA-206 regulate skeletal muscle satellite cell proliferation and differentiation by repressing Pax7. J Cell Biol 2010;190(5):867-79.

24. Winbanks CE, Wang B, Beyer C, Koh P, White L, Kantharidis P, et al. TGF- $\beta$ regulates miR-206 and miR-29 to control myogenic differentiation through regulation of HDAC4. J Biol Chem 2011;286(16):13805-14.

25. Pellegrini L. The Pol $\alpha$-primase complex. Subcell Biochem 2012;62:157-69.

26. Buckingham M, Rigby PW. Gene regulatory networks and transcriptional mechanisms that control myogenesis. Dev Cell 2014;28(3):225-38.

27. Lozano-Velasco E, Galiano-Torres J, Jodar-Garcia A, Aranega AE, Franco D. miR-27 and miR-125 distinctly regulate muscle-enriched transcription factors in cardiac and skeletal myocytes. BioMed Res Int 2015;2015:391306. doi: 10.1155/2015/391306.

28. Crist CG, Montarras D, Pallafacchina G, Rocancourt D, Cumano A, Conway SJ, et al. Muscle stem cell behavior is modified by microRNA-27 regulation of Pax3 expression. Proc Nat Acad Sci U S A 2009;106(32):13383-7.

29. Gagan J, Dey BK, Dutta A. MicroRNAs regulate and provide robustness to the myogenic transcriptional network. Curr Opin Pharmacol 2012;12(3):383-8.

30. Miretti S, Martignani E, Accornero P, Baratta M. Functional effect of mir-27b on myostatin expression: a relationship in piedmontese cattle with double-muscled phenotype. BMC Genomics 2013;14:194.

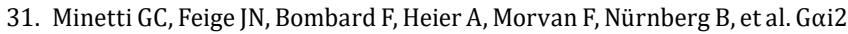
signaling is required for skeletal muscle growth, regeneration, and satellite cell proliferation and differentiation. Mol Cell Biol 2014;34(4):619-30.

32. Feng Y, Niu L-L, Wei W, Zhang WY, Li XY, Cao JH, et al. A feedback circuit between miR-133 and the ERK1/2 pathway involving an exquisite mechanism for regulating myoblast proliferation and differentiation. Cell Death Dis 2013;4(11):e934.

33. Wang XH. MicroRNA in myogenesis and muscle atrophy. Curr Opinion Clin Nutrition Metabolic Care 2013;16(3):258-66.

34. Huang MB, Xu H, Xie SJ, Zhou H, Qu LH. Insulin-like growth factor-1 receptor is regulated by microRNA-133 during skeletal myogenesis. PLoS ONE 2011;6(12):e29173. doi: 10.1371/journal.pone.0029173. 
35. Frias Fde T, de Mendonça M, Martins AR, Gindro AF, Cogliati B, Curi R, et al. MyomiRs as markers of insulin resistance and decreased myogenesis in skeletal muscle of diet-induced obese mice. Frontiers Endocrinol 2016;7:76.

36. Martin B, Pearson M, Kebejian L, Golden E, Keselman A, Carlson O, et al. Sex-dependent metabolic, neuroendocrine, and cognitive responses to dietary energy restriction and excess. Endocrinology 2007;148(9):4318-33.

37. Bernard D, Prasanth KV, Tripathi V, Colasse S, Nakamura T, Xuan Z, et al. A long nuclear-retained noncoding RNA regulates synaptogenesis by modulating gene expression. EMBO J 2010;29(18):3082-93. doi: 10.1038/ emboj.2010.199.

38. Han X, Yang F, Cao H, Liang Z. Malat1 regulates serum response factor through miR-133 as a competing endogenous RNA in myogenesis. FASEB J 2015;29(7):3054-64.

39. Duran BO, Fernandez GJ, Mareco EA, Moraes LN, Salomão RA, Gutierrez de Paula T, et al. Differential microRNA expression in fast- and slow-twitch skeletal muscle of Piaractus mesopotamicus during growth. PLoS ONE 2015;10(11):e0141967. doi:10.1371/journal.pone.0141967.

40. Porrello ER, Johnson BA, Aurora AB, Simpson E, Nam YJ, Matkovich SJ, et al. The miR-15 family regulates post-natal mitotic arrest of cardiomyocytes. Circ Res 2011;109(6):670-9.

41. Rowlands DS, Page RA, Sukala WR, Giri M, Ghimbovschi SD, Hayat I, et al. Multi-omic integrated networks connect DNA methylation and miRNA with skeletal muscle plasticity to chronic exercise in type 2 diabetic obesity. Physiol Genomics 2014;46(20):747-65.

42. Sato T, Yamamoto T, Sehara-Fujisawa A. miR-195/497 induce postnatal quiescence of skeletal muscle stem cells. Nat Commun 2014;5:4597. doi:10.1038/ncomms5597.

43. Wei W, Zhang WY, Bai JB, Zhang HX, Zhao YY, Li XY, et al. The NF- $\kappa$ Bmodulated microRNAs miR-195 and miR-497 inhibit myoblast proliferation by targeting Igf1r, Insr and cyclin genes. J Cell Sci 2016;129(1):39-50.

44. Hashemi Gheinani A, Burkhard FC, Rehrauer H, Aquino Fournier C, Monastyrskaya K. MicroRNA MiR-199a-5p regulates smooth muscle cell proliferation and morphology by targeting WNT2 signaling pathway. J Biol Chem 2015;290(11):7067-86. doi: 10.1074/jbc.M114.618694.

45. Song XW, Li Q, Lin L, Wang XC, Li DF, Wang GK, et al. MicroRNAs are dynamically regulated in hypertrophic hearts, and miR-199a is essential for the maintenance of cell size in cardiomyocytes. J Cell Physiol 2010;225(2):437-43.

46. Jia L, Li Y-F, Wu G-F, Song Z-Y, Lu HL, Song C-C, et al. MiRNA-199a-3p regulates C2C12 myoblast differentiation through IGF-1/AKT/mTOR signal pathway. Int J Mol Sci 2014;15(1):296-308. doi:10.3390/ijms15010296.

47. Chen T, Margariti A, Kelaini S, Cochrane A, Guha ST, Hu Y, et al. MicroRNA199b modulates vascular cell fate during iPS cell differentiation by targeting the Notch Ligand Jagged 1 and Enhancing VEGF signaling. Stem Cells 2015;33(5):1405-18.

48. Jackson HE, Ingham PW. Control of muscle fibre-type diversity during embryonic development: the zebrafish paradigm. Mech Dev 2013;130(9-10):447-57.
49. Van Rooij E, Quiat D, Johnson BA, Sutherland LB, Qi X, Richardson JA, et al. A family of microRNAs encoded by myosin genes governs myosin expression and muscle performance. Dev Cell 2009;17(5):662-73.

50. Wang X, Ono Y, Tan SC, Chai RJ, Parkin C, Ingham PW. Prdm1a and miR-499 act sequentially to restrict Sox6 activity to the fast-twitch muscle lineage in the zebrafish embryo. Development 2011;138(20):4399-404.

51. Nachtigall PG, Dias MC, Carvalho RF, Martins C, Pinhal D. MicroRNA-499 expression distinctively correlates to target genes sox 6 and rod 1 profiles to resolve the skeletal muscle phenotype in nile tilapia. PLoS ONE 2015;10(3):e0119804. doi: 10.1371/journal.pone.0119804.

52. Tarnowski M, Grymuła K, Tkacz M, Czerewaty M, Poniewierska-Baran A, Ratajczak MZ. Molekularne mechanizmy regulacji przerzutowania komórek nowotworowych na przykładzie mięsaka prążkowanokomórkowego (rhabdomyosarcoma). Postępy Hig Med Dośw 2014;68:258-7.

53. Raimondi L, Ciarapica R, De Salvo M, Verginelli F, Gueguen M, Martini C, et al. Inhibition of Notch3 signalling induces rhabdomyosarcoma cell differentiation promoting $\mathrm{p} 38$ phosphorylation and p21Cip1 expression and hampers tumour cell growth in vitro and in vivo. Cell Death Differ 2012;19(5):871-81.

54. Rao PK, Missiaglia E, Shields L, Hyde G, Yuan B, Shepherd CJ, et al. Distinct roles for miR-1 and miR-133a in the proliferation and differentiation of rhabdomyosarcoma cells. FASEB J 2010;24(9):3427-37. doi: 10.1096/ fj.09-150698.

55. Kostera-Pruszczyk A. Glikokortykoidy w leczeniu dystrofii mięśniowej Duchenne'a - standard postępowania. Neurol Dziec 2011;40(20):11-4.

56. Zammit PS, Relaix F, Nagata Y, Ruiz AP, Collins CA, Partridge TA, et al. Pax7 and myogenic progression in skeletal muscle satellite cells. J Cell Sci 2006;119(Pt 9):1824-32.

57. Greco S, De Simone M, Colussi C, Zaccagnini G, Fasanaro P, Pescatori M, et al. Common micro-RNA signature in skeletal muscle damage and regeneration induced by Duchenne muscular dystrophy and acute ischemia. FASEB J 2009;23(10):3335-46.

58. Quaranta MT, Spinello I, Paolillo R, Macchia G, Boe A, Ceccarini M, et al. Identification of $\beta$-dystrobrevin as a direct target of miR-143: involvement in early stages of neural differentiation. PLoS ONE 2016;11(5):e0156325.

59. Kubiszewska J, Kwieciński H. Stwardnienie boczne zanikowe. Post Nauk Med 2010;6:440-8.

60. Tsitkanou S, Della Gatta PA, Russell AP. Skeletal muscle satellite cells, mitochondria, and microRNAs: their involvement in the pathogenesis of ALS. Front Physiol 2016;7:403. doi: 10.3389/fphys.2016.00403.

61. de Andrade HM, de Albuquerque M, Avansini SH, de S Rocha C, Dogini DB, Nucci A, et al. MicroRNAs-424 and 206 are potential prognostic markers in spinal onset amyotrophic lateral sclerosis. J Neurol Sci 2016;368: 19-24.

62. Sjögren RJO, Egan B, Katayama M, Zierath JR, Krook A. Temporal analysis of reciprocal miRNA-mRNA expression patterns predicts regulatory networks during differentiation in human skeletal muscle cells. Physiol Genomics 2015;47(3):45-57. 